\title{
Implementation Of Conservation Policy Through The Protection Of Life Support System In The Karimunjawa National Park
}

\author{
Nur Anisa Eka Ariyani ${ }^{1}$, Kismartini $^{2}$ \\ ${ }^{1}$ Master Program of Environmental Science, School of Postgraduate Studies, Diponegoro University, Semarang -Indonesia \\ ${ }^{2}$ Department of Doctoral Public Administration Program, School of Postgraduate Studies, Diponegoro University, Semarang - Indonesia
}

\begin{abstract}
The Karimunjawa National Park as the only one marine protected area in Central Java, managed by zonation system has decreased natural resources in the form of decreasing mangrove forest area, coral cover, sea biota population such as clams and sea cucumbers. Conservation has been done by Karimunjawa National Park Authority through protection of life support system activities in order to protect the area from degradation. The objective of the research is to know the implementation of protection and security activities of Karimunjawa National Park Authority for the period of 2012 - 2016. The research was conducted by qualitative method, processing secondary data from Karimunjawa National Park Authority and interview with key informants. The results showed that protection and security activities in The Karimunjawa National Park were held with three activities: pre-emptive activities, preventive activities and repressive activities. Implementation of conservation policy through protection of life support system is influenced by factors of policy characteristic, resource factor and environmental policy factor. Implementation of conservation policy need support from various parties, not only Karimunjawa National Park Authority as the manager of the area, but also need participation of Jepara Regency, Central Java Provinces, communities, NGOs, researchers, developers and tourism actors to maintain and preserve existing biodiversity. Improving the quality of implementors through education and training activities, the availability of the state budget annually and the support of stakeholders is essential for conservation.
\end{abstract}

\section{Introduction}

Extinction is a natural process, but the extinction rate that reaches $1000-10,000$ times from its natural processes [1] is quite alarming. More than 77,300 species have been included in the IUCN Red List in 2015. This extinction occurs due to habitat degradation, over exploitation, pollution, disease and climate change. The threat of extinction of flora and fauna is mainly due to the high rate of population growth in Asia and Africa including Indonesia [2].

Indonesia ranks is 4 th out of 20 potential countries have extinction of biodiversity, where there are 1126 endangered species [3]. Efforts to save biodiversity both in situ and ex situ have not been satisfactory. According to the Ministry of Environment and Forests [4], Indonesia has allocated no less than 27 million hectares of land as a protected area. 51 areas designated as national parks have not been able to be a shelter because of threats of damage including The Karimunjawa National Park.

The threat of ecosystem damage occurring in the Karimunjawa Islands has prompted the government to conserve. Determination of Karimunjawa Marine Nature Reserve on April 9, 1986 through Decree of Minister of Forestry no. 123 / Kpts-II / 1986 was the first step, then on February 22, 1999 Karimunjawa was designated as a national park through Decree of Minister of Forestry number 78 / Kpts-II / 1999. The area of $111.625 \mathrm{Ha}$ consists of 22 islands with 5 The major ecosystems of coral reef ecosystems, sea grass beds, mangrove forests, coastal forests, and lowland tropical rainforests $[5,6]$.

Karimunjawa Island and Pulau Kemujan as the largest island in The Karimunjawa National Park threatened damaged mangrove ecosystem. According to research conducted by Kamal et al [7], the area of mangrove forest from 2009 to 2012 on both islands is degraded by $23.8 \mathrm{Ha}$, due to changes in land use. Similarly, what happens to coral reef ecosystems, technical reports from Wildlife Conservation Society Indonesia Program [8], shows that there is a decrease in hard coral cover from $57.86 \%$ in 2013 to $49.89 \%$ in 2016 in The Karimunjawa National Park.

Coral reef ecosystem is a habitat for various marine biota including clams and sea cucumbers. clams (Kima) as a protected animal according to PP. 7 Year 1999 About Preservation of Plant and Animal Species has decreased population in 3 islands in The Karimunjawa National Park that is Cemara Besar Island, Geleang Island and Katang Island [9]. Besides clams, sea cucumber population also decreased. The results of sea cucumber monitoring conducted by BTNKJ in 2016 found 166 sea cucumbers decreased when compared with the population of sea cucumbers monitoring results

\footnotetext{
*Corresponding author: nur anisa0429@yahoo.com
} 
in 2012 as many as 315. Population decline occurs due to habitat destruction and the over exploitation of clams and sea cucumbers.

Mangrove degradation, decreased hard coral cover and decline in marine biota population are an indication that the Ministry of Environment and Forestry through the Karimunjawa National Park Agency (BTNKJ) needs to improve its performance in the context of conservation. Efforts to manage the area must be increased, conservation through protection of life support system activities as mandated by Law No. 5 of 1990 on Conservation of Biological Natural Resources and Ecosystems have various challenges in its implementation. TNKJ still have many problems like illegal logging, illegal fishing, exploitation of protected plants and animals, destruction of infrastructure and protection of zone functions. Its problems are indicated of the lack of optimum implementation of conservation policies in The Karimunjawa National Park.

Based on the phenomenon, research on the implementation of conservation policy through the protection of life support system in The Karimunjawa National Park is important to do. The purpose of this research is to know the implementation of protection and security activities in The Karimunjawa National Park for the period of $2012-2016$.

\section{Literature review}

Public policy according to some experts $[10,11]$ is the government's decision to do or not to do something about public problems that occurred. The public policy process consists of several stages: problem identification, agenda formulation, policy formulation, policy approval, policy implementation, and policy evaluation.

Implementation of policy as one of the stages of the public policy process is very important to note. The process at this stage can be said to be crucial, because no matter how good a policy when implementation is bad then the policy will not get to the target of policy well.

The success of an implementation is influenced by several things, with reference to previous research (George C. Edward III; Donald S. Van Meter and Carl E. Van Horn; Merilee S. Grindle; Daniel A. Mazmanian and Paul A Sabatier; David L Weimer and Aidan R Vining; Maier, C., \& Winkel, G; Kalaba, FK; Muhumuza, M. , \& Balkwill, K) $[4,11,12]$ in this research will be seen the influence of policy characteristics, resources and policy environment to the successful implementation of conservation policy.

Conservation policies in Indonesia are governed by Law No. 5 of 1990 on the Conservation of Biological Natural Resources and their Ecosystems. This regulation explains that one of the conservation activities is the protection of life support system. The protection of the life support system is a natural process of biological and non-biological elements that ensures the survival of ecological creatures to improve the welfare of society and the quality of human life. The protection of the lifesupport system is carried out through prevention, prevention and restriction of damage caused by human, livestock, nature, invasive species, pests and diseases, and effectively guarding the area. Protection and security of conservation area is an activity that must be done by the institution appointed to manage the conservation area one of them is the national park.

National park is a natural conservation area that has native ecosystem, managed by zoning system which is utilized for research, science, education, cultivation, tourism and recreation purposes. Criteria of a region can be designated and designated as a national park area is to have unique natural resources and unique and unique ecosystems that are still intact and natural and unique natural phenomena; Has one or more intact ecosystems; Has sufficient breadth to ensure the sustainability of natural ecological processes; And is an area that can be divided into core zones, utilization zones, jungle zones, and / or other zones as required.

\section{Research methods}

Research conducted in The Karimunjawa National Park as the only one Marine Protected Area in Central Java with high biodiversity. The research method used qualitative approach, processing secondary data from Karimunjawa National Park Agency and interview with key informants.

Secondary data itended of Strategic Plan of Karimunjawa National Park 2015-2019, Performance Report 2012 - 2016 and report on the results of protection activities conducted in the last 5 years (20122016). The data will be collected and grouped and then analyzed qualitatively. The required secondary data is obtained from Karimunjawa National Park Agency as the technical implementation unit of the Ministry of Environment and Forestry in implementing the conservation policy.

The implementation of the conservation policy described in this study is limited to the protection of life support system activities which is conducted by BTNKJ in the last 5 years. Interview with key informant is done by researcher to be able to describe the secondary data obtained and know the factors that influence the implementation and to know whether there is a decrease of the disturbance to the area after the protection of the area. Key informants are BTNKJ employees of forest police elements and forest ecosystem controllers who doing protection and security activities of the area.

\section{Results and discussion}

The Karimunjawa National Park is geographically located at $5^{\circ} 40^{\prime} 39^{\prime \prime}-5^{\circ} 55^{\prime} 00^{\prime \prime}$ LS and $110^{\circ} 05^{\prime} 57^{\prime \prime}$ $110^{\circ} 31$ ' $15^{\prime \prime} \mathrm{BT}$ which is administratively belong to the sub-district of Karimunjawa Regency of Jepara Central Java Province can be saw in figure 1 . 


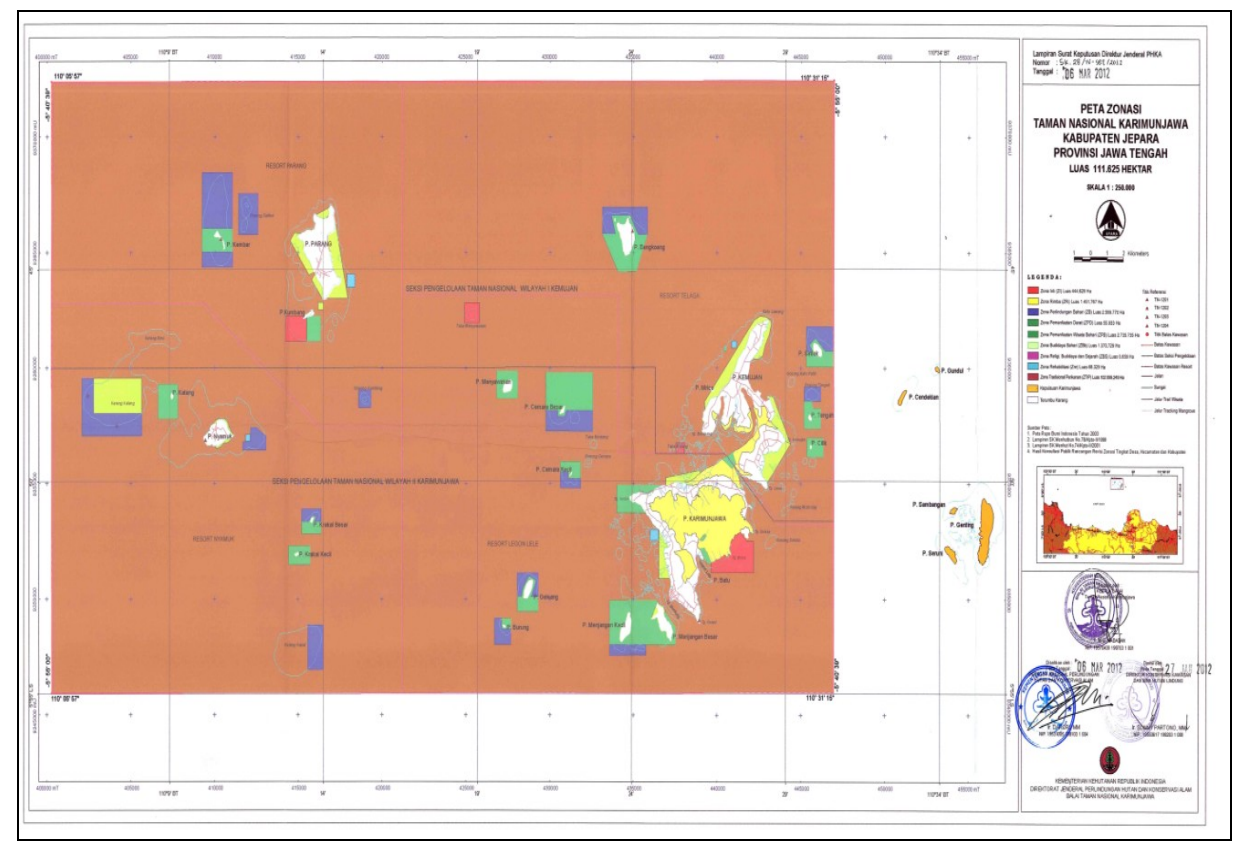

Fig. 1. Location of The Karimunjawa National Park

The total area is $111.625 \mathrm{Ha}$ with details of 1.285.50 Ha is the mainland area of Karimunjawa Island in the form of lowland tropical rain forest ecosystem, 222.20 Ha is the mainland area in Kemujan Island in the form of mangrove forest ecosystem and 110,117.30 $\mathrm{Ha}$ is the water area. TNKJ has two National Park Management Section (SPTN) namely SPTN I Kemujan and SPTN II Karimunjawa.

As a national park, TNKJ is managed by a zoning system. Based on the Decision Letter of the Director General of PHKA. SK 28 / IV-SET / 2012 on Zoning of Karimunjawa National Park, there are 9 zones within this area: core zone, jungle zone, marine protection zone, land use zone, marine tourism zone, marine culture zone, religious zone, culture and History, rehabilitation zone, traditional fishery zone.

\subsection{Implementation of the protection of life support system}

The protection of life support systems is aimed at the maintenance of ecological processes that support the viability of life to improve people's welfare and the quality of human life. To achieve these objectives, the protection of the area in The Karimunjawa National Park is implemented with 3 activities, namely Preemptive, preventive and repressive activities.

\subsubsection{Preemptive activities}

Preemptive activities are activities aimed at preventing, eliminating, reducing, closing the intentions of a person or group to commit forestry crimes. The Karimunjawa National Park Office conducts pre-emptive activities through the manufacture and maintenance of fire breaks, maintenance of the boundary limit, maintenance of reference points, light beacon maintenance, patrol tracking, zonation boundary marking, establishment and guidance of fire-concerned community (MPA), borderline maintenance, , Facilitation, guidance, assistance of community polhut partners (MMP), socialization of regulation / zoning, and fire control.

Preeminative activities through the manufacture and maintenance of fire breaks are intended to prevent the spread of flames by separating flammable materials and also to facilitate the movement of equipment and personnel in handling fires. In the Year 2012 there are 2 activities of manufacture and maintenance of fire breaks, 1 activity in 2013, 2015, 2016, and in 2014 there is no implementation of fuelbreak activities.

The next preemptive activity is the maintenance of the boundary. Borders are fixed boundary marks of a certain size made of concrete with iron frame or of durable I / II grade wood or other boundary marks installed along boundary routes. Boundary maintenance activities are very important in the work area of the Karimunjawa National Park Authority, especially those directly related to the community's landrights so that the location, position and condition of the boundary are still good to ensure legal certainty and integrity of conservation forest areas. In the last 5 years there are only 2 border maintenance activities ie 1 activity in 2013 and 1 activity in 2016 .

From the results of maintenance activities on 2016 limits at Resort Legon Lele Regional Park Management Section of Karimunjawa Region II of 292 border frontier that limits the jungle zone area with community owned land, Pal TN 1 to Pal TN 60 is located in the mangrove forest stretching from Nyamplungan Until Kemloko, TN 61 to TN 72 at Legon Moto, while TN 73 to TN 292 stretched from Kemloko to Legon Janten. 20 of them damaged in Kemloko area up to Cikmas and have been repaired through this activity.

In pre-emptive activities, BTNKJ involves communities around the region by establishing firecaring community (MPA) and the community of polhut partners (MMP). MPA is a community that voluntarily 
cares for the control of forest fires and land that have been trained / provided and can be empowered to assist forest fire control activities while MMP is a community group around the forest that helps polhut in the implementation of forest protection under coordination, coaching and Supervision of BTNKJ.

Preemptive activities can be done well if it gets enough budget from the government. The highest preemptive activity budget realization was in 2013 and the lowest was in 2015. Budget support and BTNKJ preemptive activities in the last 5 years can be seen in figure 2 .
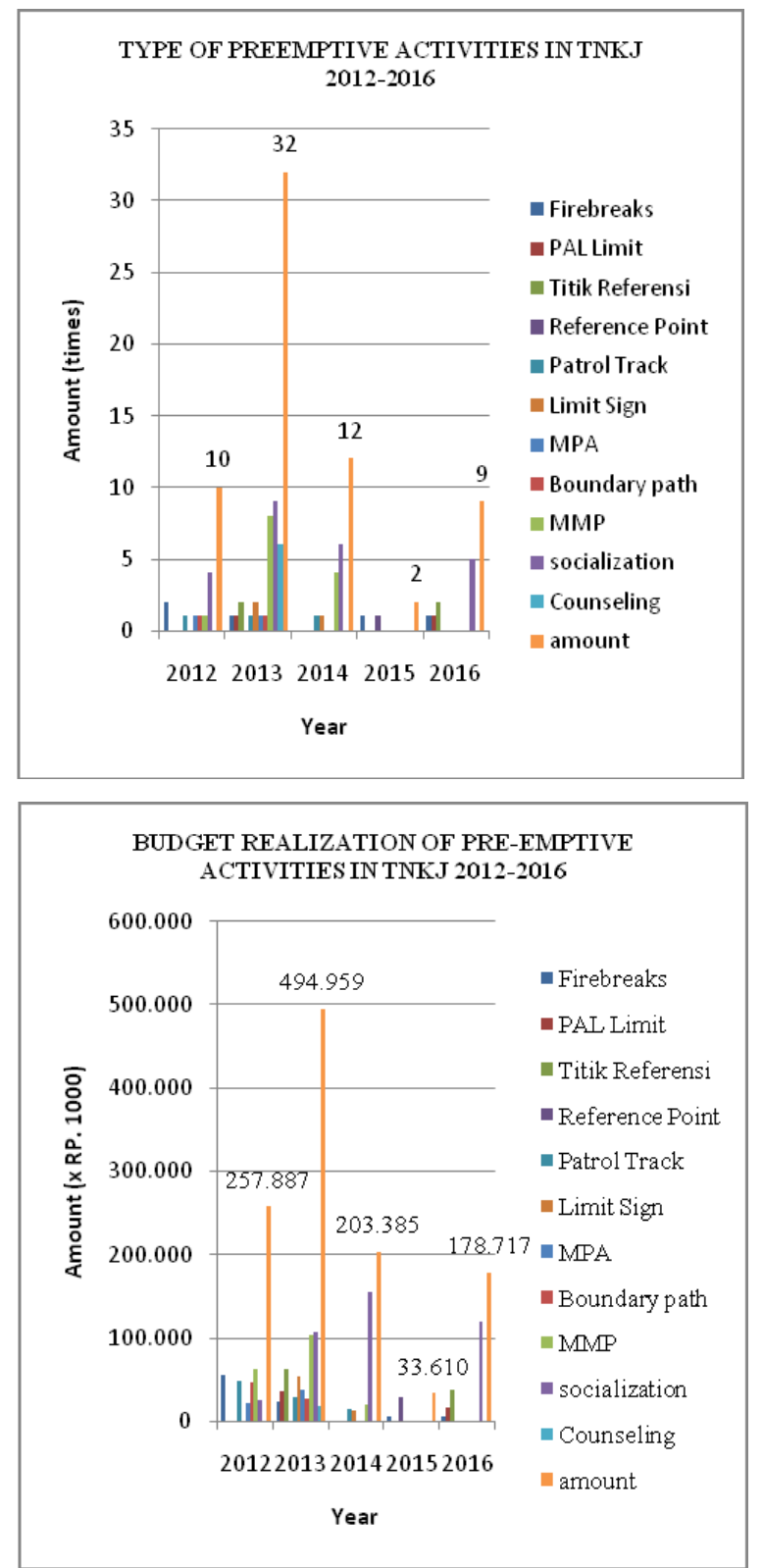

Fig. 2. Types of activities and budgets of 2012-2016 preemptive activities

\subsubsection{Preventive activities}

Preventive activities are activities aimed at preventing, eliminating, reducing, closing a person's or group's opportunity to commit forestry crimes. Preventive activities in The Karimunjawa National Park are carried out with forest fire prevention patrols, MMP joint patrols, water patrols, ground patrols, monitoring of zoning fishermen compliance, data analysis of regional security disturbances, forest fire standby apples. Patrol activity is a guarding activity to narrow the space for violation. This activity is carried out at guarded posts that have been determined based on the point of prone to the disturbance.

The frequent preventive activities in The Karimunjawa National Park are fire patrol and water patrol. Of the annual performance report data, 12 fire patrol activities were conducted in 2013, 12 water patrol activities in 2015 and 16 water patrols in 2016.
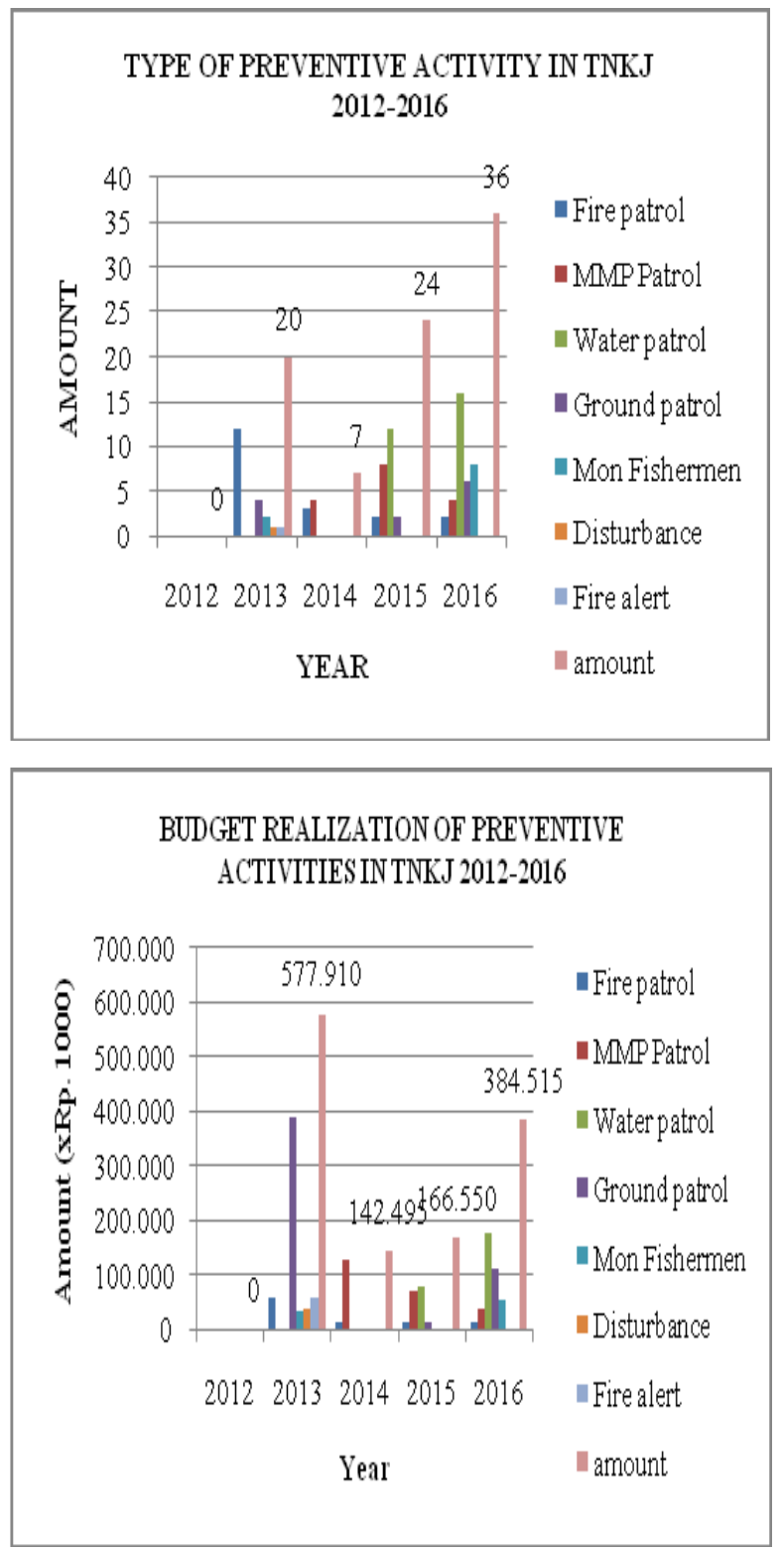

Fig. 3. Type of activities and budget of preventive activities in 2012-2016

\subsubsection{Repressive activities}

Repressive activities are non-judicial law enforcement activities to reduce, suppress or stop forestry crimes committed by a person or group. This repressive activity is carried out if the situation and condition of the 
disturbance of the security of the region occurs and tends to continue to take place even increased so that the need to immediately take action against the perpetrators. Repressive activities in The Karimunjawa National Park are conducted through investigation activities, evidence handling, justice operations, intelligence operations, aquaculture operations, joint security operations, controlling operations of TSL, ground security operations and destruction of evidence.
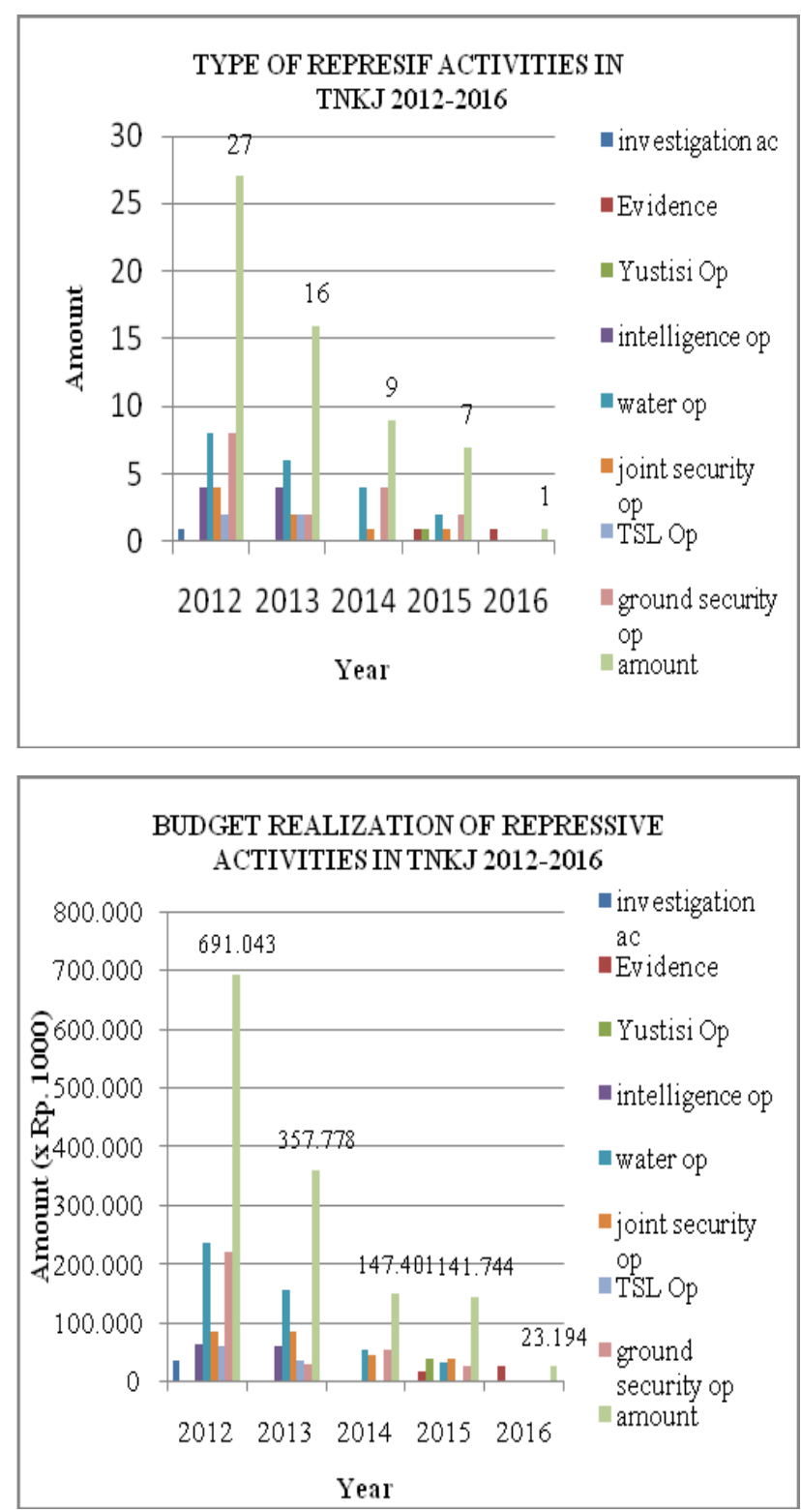

Fig. 4. Type of activities and budget of repressive activities in 2012-2016

Repressive activities frequently conducted in The Karimunjawa National Park are marine security operations and ground security operations while intelligence operations and joint security operations are sometimes performed. From the data analysis there are 20 watershed operations, 16 ground security operations, 8 activities for each intelligence operation and joint security operation in the last 5 years.
There is only one repressive activity in 2016, namely the destruction of evidence. This is because the repressive activities that were previously the authority of the directorate general (director general) Conservation of natural resources and ecosystem (KSDAE) turned into the authority of the director general of law enforcement. All forms of repressive activities are handled by this division. Type of activities and budget realization of repressive activities 2012 - 2016 can be seen in figure 4 . Number of activities and budget realization tends to decrease every year. This is a good signal for the decrease in disturbance to the region.

\subsection{Factors affecting the implementation of conservation policies}

\subsubsection{Factors of policy characteristics}

The results of interviews with key informants, conservation policies in life protection system protection activities have been in accordance with the objectives to be achieved is to ensure the survival of ecological creatures to improve the welfare of society and the quality of human life. The interests of the target group in this community around The Karimunjawa National Park have been accommodated as well as the conservation interests.

The protection activities carried out are in accordance with the master plan and zone standards so as to reduce disturbance to the area. The clarity of the program also felt that the implementor was good enough so that the activities could be implemented. There is consistency of the program, it is seen from the existence of life protection system protection activities in the last five years.

\subsubsection{Resource factor}

The Karimunjawa National Park Agency has 92 employees consisting of 75 civil servants and 17 daily employees who work in The Karimunjawa National Park Ageny, National Park Management Section I (Kemujan), National Park Management Section II (Karimunjawa) as shown in table 1 .

Table. 1 State of Employment Hall of Karimunjawa National Park Based on Group and Sex of 2016

\begin{tabular}{|c|c|c|c|c|c|c|c|c|c|}
\hline \multirow[t]{3}{*}{$\mathrm{N}_{0}$} & \multirow[t]{3}{*}{ Organizational unit } & \multirow{2}{*}{\multicolumn{4}{|c|}{$\begin{array}{c}\text { civil servants } \\
\text { Class }\end{array}$}} & \multirow{3}{*}{$\begin{array}{l}\text { daily } \\
\text { emplo } \\
\text { yees }\end{array}$} & \multicolumn{2}{|c|}{ gender } & \multirow{3}{*}{$\begin{array}{l}\text { total } \\
\text { number }\end{array}$} \\
\hline & & & & & & & \multirow[t]{2}{*}{ Male } & \multirow[t]{2}{*}{ female } & \\
\hline & & IV & III & II & sum & & & & \\
\hline 1 & $\begin{array}{l}\text { The Karimunjawa } \\
\text { National Park }\end{array}$ & 2 & 27 & 4 & 33 & 7 & 27 & 13 & 40 \\
\hline 2 & $\begin{array}{l}\text { National Park } \\
\text { Management SectionI } \\
\text { (Kemujan), }\end{array}$ & 0 & 15 & 2 & 17 & 6 & 21 & 2 & 23 \\
\hline \multirow[t]{2}{*}{3} & $\begin{array}{l}\text { National Park } \\
\text { Management Section } \\
\text { II(Karimunjawa) }\end{array}$ & 0 & 18 & 7 & 25 & 4 & 27 & 2 & 29 \\
\hline & Total number & 2 & 60 & 13 & 75 & 17 & 75 & 17 & 92 \\
\hline
\end{tabular}


From the interviews with key informants, employees in TNKJ have been sufficient in number and function. Every employee is given equal opportunity to attend education and training as an effort to improve conservation skill. The availability of APBN budgets through DIPA (List of Budget Usage Fulfillment) has been felt sufficiently since 2012-2016. Funding from outside parties whether NGOs or CSR companies support the better conservation in The Karimunjawa National Park.

\subsubsection{Environmental factors policy}

The policy environment includes the community surrounding the park, the support of relevant agencies and outside support is indispensable in the context of conservation. Given the limited capacity that is still owned by Karimunjawa National Park as a manager, BTNKJ has 4 (four) partners in realizing the conservation in TNKJ namely Wildlife Conservation Society-Indonesia Program (WCS-IP), Jakarta Animal Aid Network (JAAN), RARE and Marine and Fisheries Agency of Central Java Province. In addition to those parties, support from scientists, tourism actors and developers is also needed.

From the interviews with key informants, there is an increase in public awareness about the importance of conservation. TNKJ has also been included as a conservation area within the RTRW of Jepara District and has been proposed to be included as a conservation area within RZWP3K of Central Java Province.

\section{Conclusions and suggestions}

Implementation of conservation policy through protection of life support system activities within the period of 2012 - 2016 implemented with 3 activities of preemptive, preventive and repressive activities. Karimunjawa National Park Agency conducts preemptive activities through the manufacture and maintenance of fire breaks, maintenance of the boundary limit, maintenance of reference points, light beacon maintenance, patrol tracking, zonation boundary marking, establishment and guidance of fire-concerned community (MPA), borderline maintenance, facilitation, guidance, assistance of community polhut partners (MMP), socialization of regulation / zoning, and fire control.

Furthermore, preventive activities in Karimunjawa National Park are conducted by patrolling forest fire prevention, MMP joint patrolling, water patrolling, land patrolling, monitoring of zoning fishermen compliance, data analysis of regional security disturbances, forest fire standby apples.

For repressive activities in Karimunjawa National Park conducted through investigation activities, handling of evidence, justice operations, intelligence operations, marine security operations, joint security operations, controlling operations of TSL, ground security operations and destruction of evidence.
Implementation of conservation policies through life protection system protection activities in the period 2012 - 2016 is influenced by factors of policy characteristics, resource factors and environmental policy factors. The policy characteristics of BTNKJ are appropriate and workable to achieve the goal of conserving natural resources. Similarly, with the resources owned, the number and function of the implementor in maintaining the area of degradation has been considered sufficient. In terms of funding, the APBN has been able to support conservation activities in TNKJ. Environmental policy factors include related parties such as communities around the region, Jepara regency, Central Java Provinces, NGOs, scientists, tourism actors and developers have provided support in policy implementation in The TNKJ.

Conservation policy conservation through life protection system protection activities needs to be maintained or where possible enhanced for the preservation of biological natural resources in the TNKJ. Improving the quality of implementors through education and training activities, the availability of the state budget annually and the support of stakeholders is essential for conservation.

\section{References}

1. Laporan Tahunan Balai Taman Nasional Karimunjawa 2012-2016 [in Indonesian]

2. Joko Widodo, Bayumedia Publishing, (2006). [in Indonesian]

3. IUCN (2015)

https:/cmsdocs.s3.amazonaws.com/keydocuments/I UCN_Red_List_Brochure_2015_LOW.pdf diakses tanggal 10 Juli 2017

4. Kalaba, F. K. (2016). Journal of Forest Policy and Economics 69, 40-44. https://doi.org/10.1016/j.forpol.2016.04.004

5. Statistik Balai Taman Nasional Karimunjawa, 20122016 [in Indonesian]

6. Wildlife Consevation Society Indonesia Program, Laporan Teknis Monitoring Ekosistem Terumbu Karang Taman Nasional Karimunjawa, Bogor (2016). [In Indonesian]

7. http://lipi.go.id/berita/ancaman-kepunahan-spesiesindonesia-tertinggi-di-dunia/1669 diakses tanggal 10 Juli 2017 [in Indonesian]

8. E. H. W. Chan, and J. Hou, 46, 35-43, (2015). https://doi.org/10.1016/j.habitatint.2014.10.018

9. Balai Taman Nasional Karimunjawa, (2016) [in Indonesian]

10. Kamal, M., Hartono, H., Wicaksono, P., Adi, N. S., \& Arjasakusuma, S. Journal of Geomatics and Planning, 3(2), 107, (2016). https://doi.org/10.14710/geoplanning.3.2.107-116

11. C. Maier, and G. Winkel, Journal of Forest Policy and Economics, https://doi.org/10.1016/j.forpol.2016.12.015 
12. M. Muhumuza, and K. Balkwill, International Journal of Biodiversity (2013). 